\title{
Penerapan Prinsip Good Corporate Governance pada Kinerja Berbasis Balanced Scorecard di LPD Kabupaten Badung
}

\author{
Made Yunita Chandra Dewi ${ }^{1}$ \\ Fakultas Ekonomi dan Bisnis \\ Universitas Udayana, Indonesia
}

\author{
I Ketut Yadnyana ${ }^{2}$ \\ Fakultas Ekonomi dan Bisnis \\ Universitas Udayana, Indonesia
}

Surel : yunitachandradewi21@gmail.com

\begin{abstract}
ABSTRAK
Good Corporate Governance (GCG) merupakan sistem untuk mengatur struktur dan mekanisme dalam perusahaan sehingga mempu mendorong efisiensi dan kinerja perusahaan. Penelitian ini bertujuan untuk mengetahui pengaruh GCG terhadap kinerja berbasis balanced scorecard di LPD Kabupaten Badung. Proksi yang digunakan adalah prinsip GCG yang terdiri atas transparansi, akuntabilitas, responsibilitas, independensi, dan kewajaran. Sampel adalah 72 LPD di Badung. Data yang digunakan adalah data primer dengan kuesioner, dianalisis dengan regresi berganda. Hasil penelitian ini menunjukkan bahwa penerapan prinsip responsibilitas berpengaruh signifikan, sedangkan prinsip transparansi, akuntabilitas, independensi, dan kewajaran tidak berpengaruh signifikan terhadap kinerja berbasis Balanced scorecard.
\end{abstract}

Kata Kunci: Prinsip Good Corporate Governance; Kinerja Berbasis Balanced Scorecard.

\section{Application Of Good corporate governance Principles On Performance Based On Balanced Scorecard In LPD in Badung}

\begin{abstract}
Good corporate governance (GCG) is a system to regulate the structure and mechanism so that it can drive the efficiency and performance of the company. This study aims to determine the effect of GCG on the performance of the balanced scorecard based on the LPD in Badung. Proxies used are GCG principles consisting of transparency, accountability, responsibility, independence and fairness. Sampl are 72 LPD in Badung. primary data with questionnaires are used and analyzed by multiple regression. The results indicate that the application of the principle of responsibility has a significant effect, while the principles of transparency, accountability, independence, and reasonableness do not have a significant effect on performance based on the balanced scorecard.
\end{abstract}

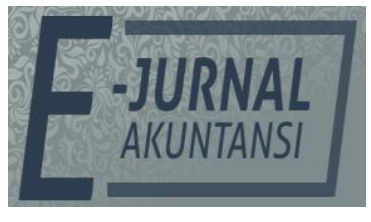

e-ISSN 2302-8556

Vol. 31 No. 5

Denpasar, Mei 2021

Hal. 1263-1276

DOI:

10.24843/EJA.2021.v31.i05.p14

PENGUTIPAN:

Dewi, M.Y.C., \& Yadnyana, I K. (2021). Penerapan Prinsip Good Corporate governance pada Kinerja Berbasis Balanced Scorecard di LPD

Kabupaten Badung. E-Jurnal Akuntansi, 31(5), 1263-1276

RIWAYAT ARTIKEL:

Artikel Masuk:

10 Maret 2021

Artikel Diterima: 25 Mei 2021

Keywords: Good Corporate Governance Principles; Performance Based Balanced Scorecard.

Artikel dapat diakses : https://ojs.unud.ac.id/index.php/Akuntansi/index 


\section{PENDAHULUAN}

LPD adalah lembaga keuangan milik desa pakraman yang berkedudukan di wewidangan desa pakraman. LPD memiliki tujuan untuk meningkatkan nilai perusahaan yang tercermin dari laba yang dihasilkan. Hasil usaha LPD tersebut telah dikontribusikan sesuai fungsi LPD untuk membangun desa pakraman. Kabupaten Badung memiliki 122 LPD, dari 122 unit LPD di Kabupaten Badung 79 LPD dinyaakan kondisi sehat, 22 LPD dinyaakan cukup sehat, sembilan LPD dinyaakan kurang sehat, empat LPD dinyaakan tidak sehat, serta delapan LPD dinyaakan bangkrut (Kusumaningtias et al., 2016).

Suatu kasus yang menjadi sorotan LPD di Kabupaten Badung adalah kasus dari LPD desa Ada Kapal yang mengalami kerugian hingga Rp 10 tmiliar lebih. Berdasarkan data tersebut membuktikan bahwa masih ada beberapa LPD di Kabupaten Badung sistem pengelolaannya masih kurang baik dan cara yang dapat digunakan untuk mengatasi hal tersebut adalah dengan menerapkan tata kelola perusahaan yang baik yang dikenal dengan istilah Good corporate governance (GCG) (Kusumaningtias et al., 2016). Halimatusadiah et al. (2015) menunjukkan perusahaan di Indonesia sadar bahwa dengan menerapkan tata kelola perusahaan yang baik kinerja perusahaan akan menjadi lebih baik dan pada akhirnya meningkatkan profitabilitas mereka, serta akan menarik investor nasional dan investor internasional. Oleh karena itu penerapan komponen GCG sangat diperlukan dalam menjalankan bisnis. GCG merupakan suatu konsep yang berdasar pada teori keagenan. Suatu organisasi seringkali mengalami konflik yang salah satunya dipicu karena perbedaan tinformasi yang diberikan kepada pemilik (principal) dari pengelola (agent) (Mahrani \& Soewarno, 2018).

Teori keagenan menjelaskan kedua pihak ingin memaksimalkan utilitasnya, maka dari itu timbul konflik keagenan. Penerapan tata kelola suatu organisasi tperlu ditingkatkan tguna tmengatasi tmasalah dalam tteori keagenan (Bendickson, 2016). Menurut Burak et al. (2017) sistem GCG menuntut dibangun dan diterapkan prinsip-prinsip GCG dalam proses manajerial sebuah perusahaan. GCG diimplementasikan untuk membangun budaya dan membangkitkan kesadaran pihak-pihak yang terkait dengan LPD agar memperhatikan tanggung jawabnya. Terdapat lima prinsip GCG yaitu Transparancy, accountability, responsibility, independency, dan fairness (Setyawan \& Dwija Putri, 2015).

Kinerja perusahaan adalah hasil yang komprehensif, pengukuran dan sistem evaluasi harus sama-sama komprehensif dan multidimensional untuk mencapai keselarasan dan keterpaduan dengan gagasan kinerjanya (Janjić et al., 2016). Penilaian kinerja dapat dilihat dalam dua aspek yaitu aspek keuangan dan aspek non keuangan. Kaplan dan Norton mengusulkan balanced scorecard sebagai pendukung dalam menilai kinerja dalam hal menyeimbangkan perspektif keuangan dan non keuangan sebagai tsatu tkesatuan dari tstrategi dimasa mendatang (Malgwi \& Dahiru, 2015). Balanced scorecard dapat digunakan sebagai alat untuk tmengukur kinerja perusahaan karena memberikan rangka komprehensif untuk menjabarkan misi ke dalam tujuan yang telah ditetapkan (Citta et al., 2019). Maharani \& Suardana (2015) dan Sandraningsih \& Putri (2015).memperoleh hasil prinsp-prinsip GCG berpengaruh positif terhadap kinerja berbasis Balanced scorecard LPD. 
Berdasarkan hasil penelitian yang dilakukan oleh Bulandari \& Damayanthi (2015) yang berjudul Pengaruh Prinsip-Prinsip GCG pada kinerja Keuangan Lembaga Perkreditan Desa di Kabupaten Badung yang menyaakan bahwa transparansi berpengaruh positif dan signifikan terhadap kinerja keuangan. Penelitian tersebut diperkuat dengan dilakukannya penelitian serupa oleh Pradnyaswari \& Putri (2016) yang berjudul pengaruh prinsip-prinsip GCG pada kinerja keuangan koperasi di kabupaten klungkung yang membuktikan bahwa transparansi berpengaruh positif dan signifikan pada kinerja keuangan koperasi di Kabupaten klungkung. Ini berarti bahwa semakin baik penerapan transparansi dalam koperasi maka semakin meningkat pula kinerja keuangan koperasi di kabupaten klungkung, begitu juga sebaliknya, semakin buruk penerapan transparansi maka kinerja keuangan koperasi akan mengalami penurunan. Pada penelitian Mahendrayasa \& Putri (2017) yang berjudul pengaruh prinsip-prinsip good corporate governance terhadap kinerja keuangan Lembaga Perkreditan Desa (LPD) Di Kota Denpasar yang membuktikan bahwa transparansi berpengaruh positif terhadap kinerja keuangan LPD.

$\mathrm{H}_{1}$ : Transparansi berpengaruh positif pada kinerja berbasis balanced scorecard.

Akuntabilitas tadalah tkejelasan dari fungsi, struktur, sistem, pelaksanaan, dan pertanggung jawaban sehingga perusahaan dapat dikelola secara efektif. Oleh sebab itu perusahaan mesti dikelola secara benar, terukur, serta sesuai dengan kepentingan perusahaan dengan tetap mempertimbangkan kepentingan dari stakeholder (Waluyo et al., 2019).

Berdasarkan penelitian yang dilakukan oleh Made \& Hapsari (2018) yang berjudul pengaruh prinsip-prinsip good governance terhadap tingkat kesehatan LPD pada LPD se kecamatan Abiansemal penelitian tersebut menyaakan bahwa akuntabilitas berpengaruh positif dan signifikan terhadap kinerja keuangan. yataan ini diperkuat dengan penelitian yang dilakukan oleh Setyawan \& Dwija Putri (2015) yang berjudul pengaruh good corporate governance terhadap kinerja keuangan lembaga pekreditan desa di kecamatan mengwi kabupaten badung. Penelitian tersebut menyaakan bahwa akuntabilitas berpengaruh positif terhadap kinerja keuangan lembaga perkreditan desa di kecamatan Mengwi Kabupaten Badung. Hal yang sama juga dikemukan oleh Quesado (2018) dan Jassem et al. (2018).

$\mathrm{H}_{2}$ : Akuntabilitas berpengaruh positif pada kinerja berbasis balanced scorecard.

Responsibilitas adalah sikap perusahaan dalam mengelola usahanya berdasarkan peraturan perundang-undangan yang berlaku (Camilleri, 2017). Penelitian yang dilakukan oleh Hindistari \& Putri (2016) mendapatkan hasil bahwa responsibilitas memiliki pengaruh positif pada kinerja Bank Perkreditan Rakyat (BPR) di Kabupaten Gianyar. Sianipar \& Wiksuana (2019) yang menyaakan bahwa responsibilitas memiliki pengaruh positif terhadap kinerja. Sesuai dengan agency theory, hal ini menunjuk bahwa dengan mematuhi segala peraturan yang ada serta melaksanakan tanggung jawab terhadap prinsipal dapat memberi dampak pada pertumbuhan LPD yang berdampak pada meningkatnya kinerja LPD.

$\mathrm{H}_{3}$ : Responsibilitas berpengaruh positif pada kinerja berbasis balanced scorecard.

Bulandari \& Damayanthi (2015) mendapatkan hasil bahwa independensi memiliki pengaruh positif terhadap kinerja keuangan LPD Kabupaten Badung. 
hal serupa juga ditemukan dalam penelitian Sandraningsih \& Putri (2015) yang mendapatkan hasil bahwa independensi memiliki pengaruh positif terhadap Kesehatan LPD di Kabupaten Badung. Penelitian oleh Wirawan \& Dwija Putri (2018) dimana independensi berpengaruh positif terhadap kinerja keuangan koperasi di kabupaten Gianyar. Pernyataan tersebut sesuai dengan agency theory, hal ini menunjukkan dengan tidak adan benturan kepentingan dalam pengelolaan LPD dapat berdampak pada meningkatnya kepercayaan prinsipal serta tingkat kesehatan LPD dan memastikan bahwa LPD telah bersikap objektif dalam pengelolaanya. hal ini tjuga tsejalan dengan penelitian yang dilakukan oleh Rajnoha \& Lorincova (2015)

$\mathrm{H}_{4}$ : Independensi berpengaruh positif pada kinerja berbasis balanced scorecard.

Dewi \& Dwijaputri (2015) menyaakan bahwa kewajaran memiliki pengaruh positif terhadap kinerja keuangan LPD di Kabupaten Gianyar. hal tersebut sejalan dengan penelitian yang dilakukan Febriani et al. (2016) yang menyimpulkan bahwa prinsip kewajaran dilakukan dengan baik maka akan semakin tinggi pula kinerja karyawan, atau sebaliknya jika prinsip kewajaran tidak dilakukan dengan baik maka kinerja karyawan juga semakin buruk. Penelitian oleh Nguyen et al. (2019) bahwa kewajaran berpengaruh positif terhadap kinerja. Sesuai dengan agency theory, hal ini menunjukkan tapabila pengelolaan LPD memperhatikan hak dari prinsipal serta memperlakukannya secara adil berdasarkan asas kewajaran dan kesetaraan maka dapat meningkatkan tingkat kesehatan LPD.

$\mathrm{H}_{5}$ : Kewajaran berpengaruh positif pada kinerja berbasis balanced scorecard.

\section{METODE PENELITIAN}

Penelitian ini merupakan penelitian kuantitatif. Lokasi penelitian dilakukan pada Lembaga Perkreditan Desa yang ada di Kabupaten Badung. Variabel bebas dalam penelitian ini adalah prinsip-prinsip good corporate governance $\left(\mathrm{X}_{1}\right)$. Variabel terikat dalam penelitian ini adalah kinerja berbasis Balanced scorecard LPD (Y). Transparansi dalam penelitian ini memiliki arti bahwa pengelola LPD harus menyampaikan seluruh informasi secara terbuka tanpa ada yang ditutupi atau sengaja disembunyikan. Aspek transparansi diukur 4 pernyataan mengenai sistem akuntansi dalam perusahaan, pengembangan teknologi, informasi manajemen, serta publikasi informasi keuangan dan informasi lain yang material mengenai perusahaan. Akuntabilitas memiliki arti bahwa akuntabilitas adalah kejelasan fungsi, struktur, sistem dan pertanggung jawaban dalam pengelolaan LPD. Aspek akuntabilitas diukur dengan 4 pernyataan yaitu pemahaman pengelola LPD, tanggungjawab pengelola LPD, Memastikan adanya sistem pengendalian internal yang efektif dalam pengelolaan LPD, dan dalam melaksankan tugas dan tanggung jawab pengelola LPD berpegang pada etika bisnis dan pedoman perilaku yang telah disepakati.

Responsibilitas dalam penelitian ini memiliki tarti bahwa pengelola LPD harus mematuhi peraturan perundang-undangan dan melaksanakan tanggung jawab sosial kepada masyarakat agar usaha dapat berjalan secara berkesinambungan. Aspek responsibilitas atau pertanggungjawaban diukur dengan 4 pernyataan mengenai ketaatan ketua dan pengawas LPD terhadap peraturan perundang-undangan dan peraturan LPD, kepedulian LPD terhadap 
lingkungan, menjadi profesional dan mematuhi etika, LPD mampu bekerja secara profesional. Indepedensi dalam penelitian ini memiliki arti bahwa pengelola LPD dalam melaksanakan kegiatannya harus secara independen dan bebas dari pengaruh pihak manapun. Aspek indepedensi diukur dengan 4 pernyataan mengenai pengambilan keputusan prajuru LPD yang obyektif atau bebas dari kepentingan berbagai pihak yang merugikan LPD, prajuru LPD dapat menghindari terjadinya dominasi oleh pihak manapun, menghindari benturan kepentingan, menjalankan aktivitas LPD dengan baik dan dinamis.

Kewajaran dalam penelitian ini memiliki arti bahwa pengelola LPD harus memperhatikan hak-hak semua pihak. Aspek kewajaran diukur dengan 4 pernyataan mengenai kesempatan krama desa/anggota LPD berpendapat, keadilan pengelola terhadap anggota, dan memberikan kesempatan yang sama dalam penerimaan karyawan bagi krama desa, wajar dalam mengungkapkan informasi. Pengukuran kinerja berbasis balanced scorecard menggunakan 12 (dua belas) pernyataan yang terdiri dari 4 perspektif, yaitu perspektif keuangan, perspektif nasabah, perspektif proses bisnis internal, serta perspektif pembelajaran dan pertumbuhan (Hindistari \& Putri, 2016) Masing-masing perspektif terdapat 3 indikator pernyataan.

Instrumen yang digunakan dalam penelitian ini merupakan kuesioner yang terdiri dari 6 bagian dengan jumlah pertanyaan 32 item. Populasi pada penelitian ini adalah seluruh LPD di Kabupaten Badung yang terdaftar di LPLPD Kabupaten Badung berjumlah 122 LPD. Metode penentuan sampel yang digunakan pada penelitian ini adalah metode nonprobability sampling dengan teknik purposive sampling. Terdapat 72 LPD yang memiliki nilai $\geq 79$ yang termasuk dari kategori LPD sehat dan sisanya 22 LPD termasuk dalam kategori cukup sehat, 15 LPD masuk dalam LPD kurang sehat, 6 LPD termasuk dalam LPD tidak sehat. Yang menjadi responden dalam penelitian ini adalah kepala LPD. Data dalam penelitian ini diperoleh dengan menggunakan metode Kuesioner, Wawancara dan Dokumentasi. Teknik analisis yang digunakan dalam penelitian ini adalah teknik analisis regresi linier berganda (multiple linear regression analysis).

\section{HASIL DAN PEMBAHASAN}

Tabel 1. Rincian Pengiriman dan Pengembalian Kuesioner

\begin{tabular}{lcc}
\hline \multicolumn{1}{c}{ Keterangan } & Jumlah & Persentase (\%) \\
\hline Kuesioner yang disebarkan & 72 & 100 \\
Kuesioner yang tidak kembali & 0 & 0 \\
Kuesioner yang dikembalikan & 72 & 100 \\
Kuesioner yang gugur (tidak lengkap) & 0 & 0 \\
Kuesioner yang digunakan & 72 & 100 \\
Tingkat pengembalian (response rate) & $72 / 72 \times 100 \%$ & 100 \\
Tingkat pengembalian yang digunakan & $72 / 72 \times 100 \%$ & 100 \\
\hline
\end{tabular}

Sumber: Data Penelitian, 2019

Berdasarkan Tabel 1, dapat diketahui bahwa dari 72 kuesioner yang disebar kepada responden, semua kuesioner tersebut kembali dengan pengisian yang lengkap dan memenuhi ketentuan sehingga tidak ada kuesioner yang gugur, perhitungan dari data tersebut menghasilkan bahwa tingkat 
pengembalian responden sebesar 100 persen, dengan tingkat pengembalian yang dianalisis sebesar 100 persen.

Jumlah responden pria sebanyak 49 orang dan jumlah responden wanita sebanyak 23 orang. Hal ini menunjukkan bahwa mayoritas responden adalah pria. Responden yang berusia $\leq 30$ tahun sebanyak 7 orang dan jumlah responden $>30$ tahun sebanyak 65 orang. Hal ini menunjukkan bahwa mayoritas responden berusia lebih dari 30 tahun. Responden yang memiliki pendidikan terakhir pada jenjang SMA sebanyak 13 torang, diploma sebanyak 0 orang, S1 sebanyak 57 orang dan S2 sebanyak 2 orang. Hal ini menunjukkan bahwa mayoritas responden memiliki tingkat pendidikan terakhir pada jenjang S1.

Tabel 2. Hasil Uji Validitas

\begin{tabular}{cccc}
\hline \multirow{2}{*}{ Variabel } & Koefisien & Nilai \\
Transparansi & X1.1 & Korelasi & Signifikansi \\
\hline Akuntabilitas & X1.2 & 0,840 & 0,00 \\
& X1.3 & 0,784 & 0,00 \\
& X2.1 & 0,833 & 0,00 \\
Responsibilitas & X2.2 & 0,624 & 0,00 \\
& X2.3 & 0,663 & 0,00 \\
& X2.4 & 0,761 & 0,00 \\
X3.1 & 0,784 & 0,00 \\
Independensi & X3.2 & 0,679 & 0,00 \\
& X3.3 & 0,720 & 0,00 \\
X3.4 & 0,850 & 0,00 \\
& X4.1 & 0,795 & 0,00 \\
& X4.2 & 0,684 & 0,00 \\
& X4.3 & 0,796 & 0,00 \\
& X4.4 & 0,819 & 0,00 \\
& X5.1 & 0,773 & 0,00 \\
& X5.2 & 0,515 & 0,00 \\
& X4.3 & 0,821 & 0,00 \\
& X5.4 & 0,858 & 0,00 \\
& & 0,835 & 0,00 \\
\hline
\end{tabular}

Sumber: Data Penelitian, 2019

Berdasarkan Tabel 2, dapat diketahui bahwa seluruh instrumen yang digunakan untuk mengukur variabel penelitian yaitu prinsip GCG adalah valid. Hal ini dibuktikan dengan nilai pearsontcorrelation tiap instrumen pernyataan yang diperoleh lebih besar dari 0,30.

Tabel 3. Uji Reliabilitas

\begin{tabular}{cc}
\hline Variabel & Cronbach's Alpha \\
\hline Transparansi & 0,757 \\
Akuntabilitas & 0,694 \\
Responsibilitas & 0,760 \\
Independensi & 0,706 \\
Kewajaran & 0,781 \\
\hline
\end{tabular}

Sumber: Data Penelitian, 2019

Variabel transparansi memiliki nilai minimum sebesar 11 dan nilai maksimum sebesar 16. Dengan nilai rata-rata 13,13 yang apabila dibagi dengan 4 item pernyataan akan menghasilkan nilai sebesar 3,2 . Hal ini berarti rata-rata 
responden memberikan skor 3 pada setiap item pernyataan variabel transparansi. Standar deviasi pada variabel ini sebesar 1,609 yang menunjukkan bahwa standar penyimpangan data terhadap nilai rata-ratanya sebesar 1,609.

Tabel 4. Hasil Statistik Deskriptif

\begin{tabular}{cccccc}
\hline & $\mathrm{N}$ & Minimum & Maximum & Mean & Std. Deviation \\
\hline Transparansi & 72 & 2,75 & 4 & 13,13 & 1,609 \\
Akuntabilitas & 72 & 3 & 4 & 13,90 & 1,406 \\
Responsibilitas & 72 & 3 & 4 & 13,90 & 1,531 \\
Independensi & 72 & 2,5 & 4 & 13,67 & 1,556 \\
Kewajaran & 72 & 2,75 & 4 & 13,67 & 1,538 \\
Balanced scorecard & 72 & 2,9 & 4 & 41,47 & 3,386 \\
\hline
\end{tabular}

Sumber: Data Penelitian, 2019

Variabel akuntabilitas memiliki nilai minimum sebesar 12 dan nilai maksimum sebesar 16. Dengan nilai rata-rata 13,90 yang apabila dibagi dengan 4 item pernyataan akan menghasilkan nilai sebesar 3,4. Hal ini berarti rata-rata responden memberikan skor 3 pada setiap item pernyataan variabel akuntabilitas. Standar deviasi pada variabel ini sebesar 1,406 yang menunjukkan bahwa standar penyimpangan data terhadap nilai rata-ratanya sebesar 1,406. Variabel responsibilitas memiliki nilai minimum sebesar 12 dan nilai maksimum sebesar 16. Dengan nilai rata-rata 13,90 yang apabila dibagi dengan 4 titem pernyataan akan menghasilkan nilai sebesar 3,4. Hal ini berarti rata-rata responden memberikan skor 3 pada setiap item pernyataan variabel responsibilitas. Standar deviasi pada variabel ini sebesar 1,531 yang menunjukkan bahwa standar penyimpangan data terhadap nilai rata-ratanya sebesar 1,531 .

Variabel independensi memiliki nilai minimum sebesar 10 dan nilai maksimum sebesar 16. Dengan nilai rata-rata 13,67 yang apabila dibagi dengan 4 item pernyataan akan menghasilkan nilai sebesar 3,4. Hal ini berarti rata-rata responden memberikan skor 3 pada setiap item pernyataan variabel independensi. Standar deviasi pada variabel ini sebesar 1,556 yang menunjukkan bahwa standar penyimpangan data terhadap nilai rata-ratanya sebesar 1,556. Variabel kewajaran memiliki nilai minimum sebesar 11 dan nilai maksimum sebesar 16. Dengan nilai trata-rata 13,67 yang apabila dibagi dengan 4 titem pernyataan akan menghasilkan nilai sebesar 3,4. Hal ini berarti rata-rata responden memberikan skor 3 pada setiap item pernyataan variabel kewajaran. Standar deviasi pada variabel ini sebesar 1,538 yang menunjukkan bahwa standar penyimpangan data terhadap nilai rata-ratanya sebesar 1,538 . Variabel balanced scorecard memiliki nilai minimum sebesar 35 dan nilai maksimum sebesar 48. Dengan nilai rata-rata 41,47 yang apabila dibagi dengan 12 item pernyataan akan menghasilkan nilai sebesar 3,4. Hal ini berarti rata-rata responden memberikan skor 3 pada setiap item pernyataan variabel balanced scorecard. Standar deviasi pada variabel ini sebesar 3,386 yang menunjukkan bahwa standar penyimpangan data terhadap nilai rata-ratanya sebesar 3,386.

Nilai Asymp.Sig (2-tailed) dari Uji normalitas adalah sebesar 0,200 atau lebih besar dari a 0,05. hal ini menunjukkan bahwa model dalam penelitian ini berdistribusi normal. Sehingga dapat disimpulkan bahwa data yang digunakan dalam penelitian ini tmerupakan data yang terdistribusi dengan normal. 
Tabel 5. Uji Normalitas

\begin{tabular}{llr}
\hline & & Unstandardized Residual \\
\hline $\mathrm{N}$ & & 72 \\
Normal tParameters ${ }^{a, b}$ & Mean &, 0000000 \\
& Std.tDeviation & 3,06248877 \\
Most tExtreme differences & Absolute &, 054 \\
& Positive &, 054 \\
& Negative &,- 051 \\
Test tStatistic & &, 054 \\
Asymp. Sig. $t(2$-tailed) & &, $200^{\mathrm{c}, \mathrm{d}}$ \\
\hline
\end{tabular}

Sumber: Data Penelitian, 2019

Berdasarkan hasil Uji Multikolinieritas dapat diketahui bahwa tidak ada variabel independen yang memiliki nilai tolerance $\leq 0,10$ dan nilai VIF $\geq \mathrm{t} 10$. Analisis ini menunjukkan bahwa tidak terdapat gejala multikolinearitas terhadap variabel penelitian.

Tabel 6. Hasil Uji Multikolinearitas

\begin{tabular}{ccc}
\hline Variabel & Tolerance & VIF \\
\hline Transparansi t & 0,613 & 1,613 \\
Akuntabilitas t & 0,412 & 2,430 \\
Responsibilitas t & 0,419 & 2,386 \\
Independensi t & 0,618 & 1,617 \\
Kewajaran t & 0,719 & 1,391 \\
\hline
\end{tabular}

Sumber: Data Penelitian, 2019

Berdasarkan hasil Uji heteroskedastisitas, dapat diketahui bahwa nilai

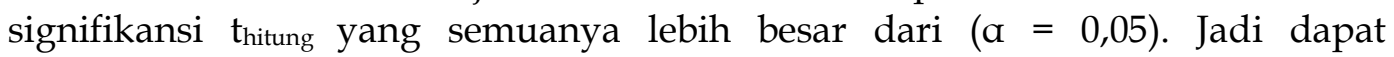
disimpulkan bahwa pada model regresi tidak ditemukan gejala heteroskedastisitas.

Tabel 7. Hasil Uji Heteroskedastisitas

\begin{tabular}{ccc}
\hline Variabel & $\mathrm{T}$ & Sig \\
\hline Transparansi & 0,187 & 0,852 \\
Akuntabilitas & 0,047 & 0,962 \\
Responsibilitas & $-0,087$ & 0,931 \\
Independensi & $-1,034$ & 0,305 \\
Kewajaran & 1,26 & 0,212 \\
\hline
\end{tabular}

Sumber: Data Penelitian, 2019

Nilai konstanta Sebesar 27,329 menunjukkan bahwa apabila nilai transparansi, akuntabilitas, responsibilitas, independensi, kewajaran bernilai konstan, maka variabel kinerja berbasis balanced scorecard $(\mathrm{Y})$ memiliki nilai positif sebesar 27,329. Nilai koefisien regresi variabel transparansi sebesar 0,020. Nilai koefisien yang positif menunjukkan bahwa semakin baik penerapan transparansi, maka semakin meningkat kinerja berbasis balanced scorecard di LPD Kabupaten Badung dengan asumsi variabel bebas lainnya dianggap konstan. Nilai koefisien regresi variabel akuntabilitas sebesar -0,310. Nilai koefisien yang negatif menunjukkan bahwa semakin buruk penerapan akuntabilitas, maka semakin menurun kinerja berbasis balanced scorecard di LPD Kabupaten Badung dengan asumsi variabel bebas lainnya dianggap konstan.

Nilai koefisien regresi variabel responsibilitas sebesar 0,812. Nilai koefisien yang positif menunjukkan bahwa semakin baik penerapan responsibilitas, maka 
semakin meningkat kinerja berbasis balanced scorecard di LPD Kabupaten Badung dengan asumsi variabel bebas lainnya dianggap konstan. nilai koefisien regresi variabel independensi sebesar $-0,012$. Nilai koefisien yang tnegatif menunjukkan bahwa semakin buruk penerapan independensi, maka semakin menurun kinerja berbasis balanced scorecard di LPD Kabupaten Badung dengan asumsi variabel bebas lainnya dianggap konstan. Nilai koefisien regresi variabel kewajaran sebesar 0,518 . Nilai koefisien yang positif menunjukkan bahwa semakin baik penerapan kewajaran, maka semakin meningkat kinerja berbasis balanced scorecard di LPD Kabupaten Badung dengan asumsi variabel bebas lainnya dianggap konstan.

Tabel 8. Hasil Analisis Linear Berganda

\begin{tabular}{|c|c|c|c|c|c|c|}
\hline \multirow{2}{*}{\multicolumn{2}{|c|}{ Model }} & \multicolumn{5}{|c|}{ Unstandardized Coefficients $\begin{array}{c}\text { Standardized } \\
\text { Coefficients }\end{array}$} \\
\hline & & $\mathrm{B}$ & Std. Error & Beta & $\mathrm{t}$ & Sig. \\
\hline 1 & (Constant) & 27,329 & 4,538 & & 6,022 & 000 \\
\hline & Transparansi & 020 & 299 & 010 & 067 & 947 \\
\hline & Akuntabilitas &,- 310 & ,418 &,- 129 &,- 742 & 460 \\
\hline & Responsibilitas & 812 & 380 & 367 & 2,133 & 037 \\
\hline & Independensi & -,012 & ,308 & -,006 &,- 039 & ,969 \\
\hline & Kewajaran &, 518 & 289 & 235 & 1,790 & ,078 \\
\hline
\end{tabular}

Sumber: Data Penelitian, 2019

Nilai koefisien adjusted $\mathrm{R}^{2}$ adalah 0,120. Hal ini menunjukkan bahwa 12 persen variasi kinerja berbasis balanced scorecard dapat dijelaskan oleh variasi dari kelima variabel independen yaitu tranparansi, akuntabilitas, responsibilitas, independensi, kewajaran. Sedangkan sisanya 88 persen dijelaskan faktor lain diluar model.

Tabel 9. Hasil Uji Koefisien Determinasi

\begin{tabular}{lllll}
\hline Model & $\mathrm{R}$ & $R$ tSquare & Adjusted $t R$ tSquare & $\begin{array}{l}\text { Std. tError tof the } \\
\text { tEstimate }\end{array}$ \\
\hline 1 & 0,426 & 0,182 & 0,120 & 3,176 \\
\hline
\end{tabular}

Sumber: Data Penelitian, 2019

Dari Hasil Uji F test didapatkan hasil bahwa nilai $F$ sebesar 2,935 dengan tingkat signifikansi 0,019. Karena tingkat signifikansi 0,019<0,05 maka model regresi dapat dikaakan bahwa prinsip transparansi, akuntabilitas, responsibilitas, independensi, kewajaran secara bersama-sama berpengaruh terhadap kinerja balanced scorecard, dengan demikian maka data tersebut layak digunakan sebagai alat untuk menguji pengaruh variabel bebas terhadap variabel terikat.

Tabel 10. Hasil Uji F

\begin{tabular}{lccccc}
\hline \multicolumn{1}{c}{ Model } & Sum of Square & Df & Mean Square & F & Sig. \\
\hline Regression & 148,047 & 5 & 29,609 & 2,935 & 0,019 \\
Residual & 665,897 & 66 & 10,089 & & \\
Total & 833,944 & 71 & & & \\
\hline
\end{tabular}

Sumber: Data Penelitian, 2019

Variabel transparansi memiliki koefisien regresi sebesar 0,670 dengan tingkat nilai signifikansi sebesar 0,947 yang lebih besar dari $a=0,05$. Pengujian ini menunjukkan bahwa variabel transparansi tidak berpengaruh signifikan terhadap kinerja berbasis balanced scorecard di LPD. Sehingga $\mathrm{H}_{1}$ ditolak. Hal ini disebabkan karena transparansi belum dilakukan dengan baik seperti 
keterbukaan mengenai informasi laporan keuangan yang transparan, dan tproses pengambilan keputusan. Apabila dalam pengelolaan LPD menerapkan prinsip transparansi seperti menyajikan laopran keuangan secara terbuka, proses pengambilan keputusan yang transparan melalui rapat, dan adanya keterbukaan mengenai informasi maka akan mampu meningkatkan kinerja LPD.

Variabel akuntabilitas memiliki koefisien regresi sebesar t-0,742 dengan nilai signifikansi sebesar $\mathrm{t} 0,460$ yang lebih besar dari $a=0,05$. Pengujian ini menunjukkan bahwa variabel akuntabilitas tidak berpengaruh signifikan terhadap kinerja berbasis balanced scorecard di LPD. Sehingga $\mathrm{H}_{2}$ ditolak. hal ini menunjukkan bahwa masih kurangnya penerapan tentang prinsip akuntabilitas di LPD tersebut dimana yang belum adanya kejelasan pertanggungjawaban sesuai struktur LPD, agar bisa meningkatkan kinerja LPD. Apabila dalam pengelolaan LPD menerapkan prinsip akuntabilitas seperti adanya kejelasan pertanggungjawaban sesuai struktur LPD, pemahaman yang baik mengenai visi, misi, dan tujuan dan target operasioanl LPD maka akan mampu meningkatkan kinerja LPD.

Variabel responsibilitas memiliki koefisien regresi sebesar 2,133 dengan nilai signifikansi sebesar 0,037 yang lebih kecil dari $a=0,05$. Pengujian ini menunjukkan bahwa variabel responsibilitas positif dan berpengaruh tsignifikan pada kinerja berbasis balanced scorecard sehingga rumusan hipotesis $\mathrm{H}_{3}$ diterima. Hal ini terjadi karena penerapan prinsip responsibilitas pada LPD yang berkaitan dengan pemahaman dan taat terhadap seluruh peraturan perundang-undangan dan peraturan LPD yang berlaku sudah diberlakukan. Hal ini menunjukkan bahwa apabila semakin tinggi prajuru LPD memahami dan mentaati seluruh peraturan perundang-undangan yang berlaku maka akan berimplikasi pada semakin tingginya kinerja LPD. Apabila dalam pengelolaan LPD menerapkan prinsip responsibilitas seperti mentaati peraturan perundang-undangan dan peraturan LPD, kepedulian terhadap masyarakat serta kesesuaian terhadap prosedur dan sistem yang diterapkan maka akan mampu meningkatkan kinerja LPD.

Variabel independensi memiliki koefisien regresi sebesar -0,039 dengan nilai signifikansi sebesar 0,969 yang lebih besar dari $\alpha=0,05$. Pengujian ini menunjukkan bahwa variabel independensi tidak berpengaruh signifikan terhadap kinerja berbasis balanced scorecard di LPD sehingga rumusan hipotesis $\mathrm{H}_{4}$ ditolak. Hal ini dimungkinakan terjadi karena dalam proses pengambilan keputusan, ketua LPD belum dapat mengambil keputusan secara objektif atau bebas dari kepentingan berbagai pihak yang dapat merugikan LPD, selain itu ketua LPD juga belum dapat menghindari adanya dominasi oleh pihak lain, mengingat peran LPD yang sangat strategis, maka tidak heran banyak orang yang ingin ambil bagian dalam pengelolaan LPD tersebut. Sehingga dapat dikaakan bahwa penerapan prinsip independensi dalam pengelolaan LPD belum dapat dilakukan dengan baik. Apabila dalam pengelolaan LPD menerapkan prinsip independensi seperti ketua dan pengelolaan LPD tidak boleh saling mencampuri dalam pelaksanaan tugas, hak, dan kewajiban masing-masing, serta tidak adanya intervensi dari pihak yang dapat merugikan LPD maka akan mampu meningkatkan kinerja keuangan LPD. 
Variabel kewajaran memiliki koefisien regresi sebesar 1,790 dengan nilai signifikansi sebesar 0,078 yang lebih besar $a=0,05$. Pengujian ini menunjukkan bahwa kewajaran tidak berpengaruh signifikan terhadap kinerja berbasis Balanced scorecard LPD sehingga rumusan hipotesis $\mathrm{H}_{5}$ ditolak. Hal ini mengindikasikan bahwa penerapan tprinsip kewajaran pada LPD dapat dikaakan tcukup baik. Kewajaran yang dimaksud yaitu memberikan kesempatan yang sama para krama desa anggota LPD untuk memberikan masukan dan pendapat pada LPD, memberikan perlakuan adil kepada semua anggota serta memberikan kesempatan yang sama dalam penerimaan karyawan LPD bagi krama desa. Tetapi walaupun penerapan prinsip ini dapat dikaakan cukup baik, nyatanya masih belum dapat mendorong peningkatan kinerja LPD, sehingga perlu dilakukan peningkatan dalam proses penerapan prinsip ini secara berkelanjutan, sehingga diharapkan akan berdampak pada peningkatan kinerja LPD. Apabila dalam pengelolaan LPD menerapkan prinsip kewajaran seperti tmemperlakukan tseluruh tpihak-pihak yang tberkepentingan dengan LPD secara adil, tidak memihak, setara dan wajar, baik itu untuk para anggota maupun kepada krama desa maka akan mampu meningkatkan kinerja LPD.

Penelitian ini diharapkan akan memberikan kontribusi positif bagi semua pihak khususnya LPD di Kabupaten Badung dalam meningkatkan kinerja berbasis balanced scorecard. Penelitian ini juga menjelaskan bahwa prinsip-prinsip GCG wajib diterapkan sehingga terciptanya solusi yang akan mempermudah LPD maupun perusahaan lainnya dalam meningkatkan kinerja, maupun meningkatkan kesejahteraan masyarakat maupun lembaga yang terkait. Temuan penelitian ini memberikan kontribusi bahwa responsibilitas yang merupakan pilar Good corporate governance berpengaruh pada kinerja berbasis Balanced scorecard. Sementara itu transparansi, akuntabilitas, independensi, kewajaran tidak berpengaruh pada kinerja berbasis balanced scorecard. Temuan ini kemungkinan disebabkan oleh komponen disaat responsibilitas menjadi fokus perhatian manajemen. Maka transparansi, akuntabilitas, independensi, kewajaran dipandang sebagai sesuatu yang wajib untuk diterapkan. Pentingnya perhatian manajemen pada responsibilitas dibandingkan dengan pilar Good corporate governance yang lainnya, merupakan fenomena menarik untuk bahan penelitian selanjutnya.

\section{SIMPULAN}

Pada variabel dependen yang diukur dengan menggunakan kuesioner menunjukkan bahwa pada prinsip independensi hasil jawaban responden menunjukkan jumlah paling rendah diantara prinsip lainnya. Berdasarkan hasil penelitian yang telah diuraikan, maka dapat ditarik simpulan yaitu penerapan prinsip responsibilitas berpengaruh signifikan terhadap kinerja berbasis balanced scorecard. Sementara itu prinsip tranparansi, akuntabilitas, independensi dan kewajaran tidak berpengaruh terhadap kinerja berbasis balanced scorecard. Dimana tpara tPrajuru LPD tsecara ttidak tlangsung akan menerapkan prinsip responsibilitas yang sudah mengandung unsur transparansi, akuntabilitas, independensi, dan kewajaran pada tsaat LPD melaporkan pertanggung jawaban kepada krama desa. 
Saran yang dapat diberikan berkaitan dengan tsimpulan tyaitu penerapan prinsip-prinsip responsibilitas adalah salah satu faktor pendorong tercapainya kinerja berbasis balanced scorecard yang lebih baik. Oleh karena itu, sebaiknya LPD di Kabupaten Badung selalu menjaga dan menerapkan mutu penerapan prinsip responsibilitas tersebut. Responsibilitas merupakan prinsip GCG yang paling baik berpengaruh sehingga dapat dikaakan prinsip ini lebih dominan diperhatikan oleh LPD di Kabupaten Badung, namun ada baiknya prinsipprinsip seperti transparansi, akuntabilitas, independensi, dan kewajaran perlu ditingkatkan penerapannya agar tercipta keseimbangan penerapan prinsipprinsip Good corporate governance sehingga dapat meningkatkan kinerja berbasis Balanced scorecard. Sosialisasi tentang prinsip-prinsip GCG perlu dikembangkan kepada seluruh prajuru LPD, agar mudah dipahami serta diingat sehingga LPD dapat lebih mudah dalam tpencapaian tujuannya.

\section{REFERENSI}

Bendickson, J. (2016). Agency theory: the times, they are a-changin'. Management Decision, 54(1), 174-193. https://doi.org/10.1108/MD-02-2015-0058

Bulandari, I., \& Damayanthi, I. (2015). Pengaruh Prinsip-Prinsip Good corporate governance Pada Kinerja Keuangan Lembaga Perkreditan Desa Di Kabupaten Badung. E-Jurnal Akuntansi, 8(3), 630-648.

Burak, E., Erdil, O., \& Altindağ, E. (2017). Effect Of Corporate Governance Principles On Business Performance. Australian Journal of Business and Management Research, 5(7), 8-21. Retrieved from Insitutionalization, Corporate Governance, Business Performance JEL

Camilleri, M. (2017). Corporate Sustainability and Responsibility: Creating Value for Business, Society and the Environment. IOSR Journal of Businees an Management, 9(1), 1-12. https:// doi.org/10.1186/s41180-017-0016-5

Citta, A. B., Ridha, A., Dekrita, Y. A., \& Yunus, R. (2019). Integration of Balanced scorecard and Analytical Hierarchy Process as a Tool for Determining the Priority of the Program Strategy: Case Study in Dr.Tc.Hillers Maumere Hospital. Advances in Economics, Business and Management Research (AEBMR), 92(1), 119-126.

Dewi, K. K., \& Dwijaputri, I. M. A. (2015). Pengaruh Penerapan Prinsip-Prinsip Gcg Pada Kinerja Keuangan Lembaga Perkreditan Desa Kabupaten Gianyar Bali. E-Jurnal Akuntansi Universitas Udayana 7.3 (2015): 559-573, 3(ISSN: 23028556), 559-573.

Febriani, J. I., Musadieq, M. Al, \& Afrianty, T. W. (2016). Pengaruh Good corporate governance terhadap Kinerja (Studi Pada Karyawan PT Pos Indonesia (Persero) Tuban). Jurnal Administrasi Bisnis, 32(1), 82-89.

Halimatusadiah, E., Sofianty, D., \& Ermaya, N. H. (2015). Effects of The Implementation of Good corporate governance on Profitability. European Journal of Business and Innovation Research, 3(4), 19-35.

Hindistari, R., \& Putri, A. D. (2016). Pengaruh Penerapan Prinsip-Prinsip Good corporate governance Pada Kinerja Bank Perkreditan Rakyat Kabupaten Gianyar. E-Jurnal Akuntansi, 16(1), 101-128.

Janjić, V., Todorović, M., \& Jovanović, D. (2016). A Comparative Analysis of Modern Performance Measurement and Management Models of 
Companies. Economic Themes, 53(2), 298-313. https://doi.org/10.1515/ethemes-2015-0017

Jassem, S., Azmi, A., \& Zakaria, Z. (2018). Impact of sustainability balanced scorecard types on environmental investment decision-making. Sustainability (Switzerland), 10(2), 1-10. https:// doi.org/10.3390/su10020541

Kusumaningtias, R., Ludigdo, U., Irianto, G., \& Mulawarman, A. D. (2016). Rethinking of Corporate Governance. Procedia - Social and Behavioral Sciences, 219(1), 455-464. https:/ / doi.org/10.1016/j.sbspro.2016.05.020

Made, N., \& Hapsari, M. (2018). E-Jurnal Akuntansi Universitas Udayana Pengaruh Prinsip-Prinsip Good Governance Terhadap Tingkat Kesehatan LPD pada LPD Se-Kecamatan Abiansemal Fakultas Ekonomi dan Bisnis Universitas Udayana ( Unud ), Bali , Indonesia email : madanihapsari9@gmail.com / T. E-Jurnal Akuntansi Universitas Udayana, 25(01), 54-82.

Maharani, I., \& Suardana, K. (2015). Pengaruh Corporate Governance, Profitabilitas, Dan Karakteristik Eksekutif Pada Tax Avoidance Perusahaan Manufaktur. E-Jurnal Akuntansi, 9(2), 525-539.

Mahendrayasa, P. K. A., \& Putri, I. G. A. M. A. D. (2017). Pengaruh Prinsipprinsip Good corporate governance Terhadap Kinerja Keuangan Lembaga Perkreditan Desa (LPD) di Kota Denpasar. E-Jurnal Akuntansi Unud, 21(2), 955-970.

Mahrani, M., \& Soewarno, N. (2018). The effect of good corporate governance mechanism and corporate social responsibility on financial performance with earnings management as mediating variable. Asian Journal of Accounting Research, 3(1), 41-60. https://doi.org/10.1108/ajar-06-2018-0008

Malgwi, A. A., \& Dahiru, H. (2015). Balanced scorecard financial measurement of organizational performance: A review. IOSR Journal of Economics and Finance, 4(6), 01-10. https:/ / doi.org/10.9790/5933-0460110

Nguyen, N. P., Evangelista, F., \& Kieu, T. A. (2019). The contingent roles of perceived budget fairness, budget goal commitment and vertical information sharing in driving work performance. Journal of Asian Business and Economic Studies, 1(1), 1-20.

Pradnyaswari, L., \& Putri, I. (2016). Pengaruh Prinsip-Prinsip Good corporate governance Pada Kinerja Keuangan Koperasi Di Kabupaten Klungkung. EJurnal Akuntansi, 14(2), 1064-1091.

Quesado, P. (2018). Advantages and contributions in the balanced scorecard implementation. Intangible Capital, 14(1), 1-10.

Rajnoha, R., \& Lorincova, S. (2015). Strategic Management of Business Performance Based on Innovations and Information Support in Specific Conditions of Slovakia. Journal of Competitiveness, 7(1), 3-21. https://doi.org/10.7441/joc.2015.01.01

Sandraningsih, K., \& Putri, A. (2015). Pengaruh Prinsip-Prinsip Good corporate governance Pada Kinerja Keuangan Lembaga Perkreditan Desa Kecamatan Abiansemal. E-Jurnal Akuntansi, 11(3), 878-893.

Setyawan, K., \& Dwija Putri, I. (2015). Pengaruh Good corporate governance Terhadap Kinerja Keuangan Lembaga Pekreditan Desa Di Kecamatan Mengwi Kabupaten Badung. E-Jurnal Akuntansi, 5(3), 586-598. 
Sianipar, R. H., \& Wiksuana, I. G. B. (2019). the Study of Effect of Good corporate governance on Financial Performance. Russian Journal of Agricultural and Socio-Economic Sciences, 86(2), 166-170. https://doi.org/10.18551/rjoas.201902.19

Waluyo, M., Huda, S., \& Soetjipto, N. (2019). Analysis of Balance Scorecards Model Performance and Perspective. MATEC, 02(3), 1-8.

Wirawan, A. . G. B. P., \& Dwija Putri, I. G. A. M. A. (2018). Pengaruh Penerapan Prinsip-Prinsip Good corporate governance dan Manajemen Risiko Pada Kinerja Keuangan Koperasi di Kabupaten Gianyar. E-Jurnal Akuntansi, 23, 1791. https://doi.org/10.24843/eja.2018.v23.i03.p07 